$\begin{array}{crcc}\text { 運輸省港湾技術研究所 } & \text { 正会員 } & \text { 神田 } & \text { 勝己 } \\ \text { 運輸省第五港湾建設局 } & \text { 斎藤 } & \text { 純 } \\ \text { 運輸省第五港湾建設局 } & \text { 皆川 } & \text { 国秋 }\end{array}$

1.はビめに

都市の臨海部は従来港湾などの物流拠点や工業用地と しての利用が大部分であったが、都市における経済活動 の活発化や人口の增加が進み商業·業務用地や住宅、レク リエーションなどの需要が增加してくると臨海部も、都市 に残された水際線を持った貫重な空間として多粎な利用 が計画されるようになっている。この結果 港湾は更に沖 合への展開を余儀なくされるが、こうした海域は大水深、 大波浪更に軟弱地盤など従来の港湾の適地としての条件 を備えていない場合も多く、こうした敩しい条件下での 港湾施設の建設技術が必要となってきた。また同時に皦 しい財政事情から経費の削減への要請も益々強いものと なっている。

本消波ブロック内蔵双胴型ケーソンは、下田港の湾口 防波堤の新断面として開発中のものであるが今後の海洋 開発における有益な着底式構造物として考えられるので そのケーソンの開発経緯、水理模型実験などについて報告 するものである。

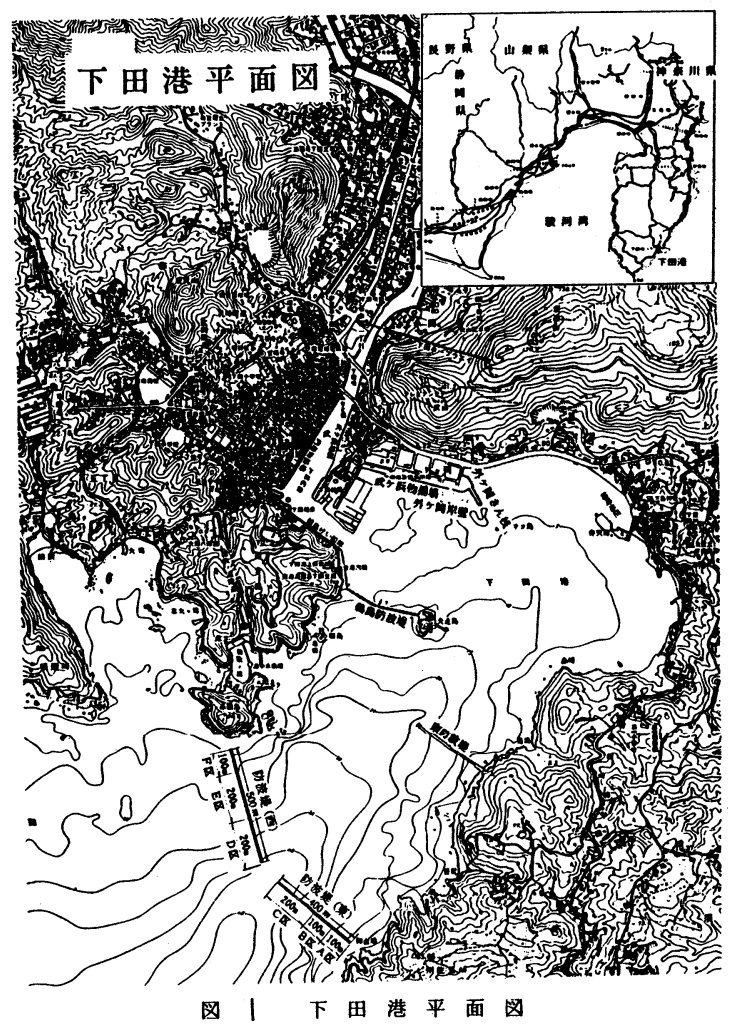

2. 下田港湾口防波堤に係る技術的課題

(1) 湾口防波堤の目的

下田港は江戸時代から東西日本を結ぶ海上交通の要衝として利用されてきた。特に周辺海域は荒天となる ことが多く避難場所としての利用が多く、昭和 26 年には避難港として指定されている。また下田港とその 背後の市街地は過去数度にわたり地震・津波の襲来があり、特に安政地震(1854年)の津波では死者122名にも 達する甚大な被害を受けているがそれ以降巨大地震がなくマグニチュード8程度の地震(東海地震)の発生が予 想されている。

こうした状況を踏まえ、荒天時に周辺海域を航行する船船が安全に避泊する水域の確保と、下田港やその 背後を津波から防護するため湾口防波堤が計画された。

(2) 防波堤周辺の条件と課題

防波堤が計画されている湾口部は海底勾配が急で深い ところは $35 m \sim 42 \pi$ あ。このため通常の消波ブロック被 堭堤やスリットケーソン堤などではケーソンの構造が大 きくなり大水深部で大量のブロックを要することから工 費が割高となるほかマウンドの捨石均しが困難なため、 マウンドに不陸の発生が予想される。波浪については、

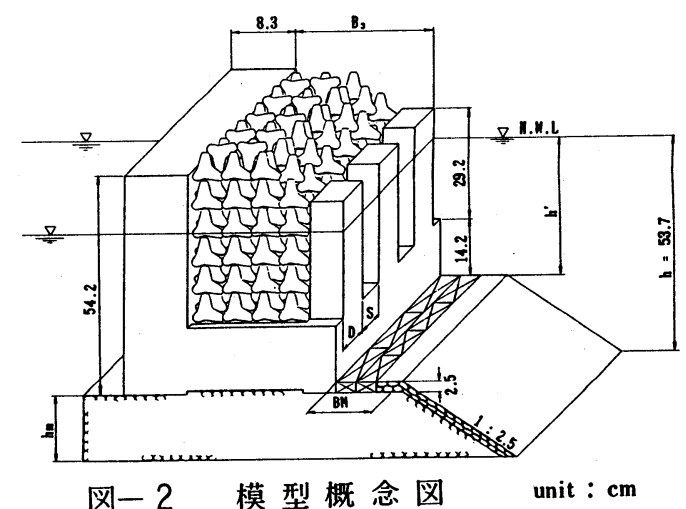

図一 2 模 型 概 念図 unit : cm 
沖波(50年碓率 $\mathrm{H}^{1 / 3}=16 \mathrm{~m} \quad \mathrm{~T}^{1 / 3}=17.4 \mathrm{sec}$ ) より港内の静稳を碓保するほか、東海地震津波 ( $\mathrm{H}=28 \mathrm{~m}$

$\mathrm{T}=20 \mathrm{~min})$ のピークカット効果が要請される。

3. 消波ブロック内蔵双胴型ケーソンの概要

消波ブロック内蔵双胴型ケーソンはこうした課題に対応して提案された新構造の堤体である。この防波堤は 、ケーソン前部の直立柱と後壁の間に消波ブロックを内蔵しているため、ブロックによる波エネルギー低減効 果と双胴間の位相差による反射波の低減が可能となるほか、深部のブロックを節約できる。また底版の一部を 無底函としているため、この部分の捨石均しが不要であり、なおかつ底版部とマウンド間の石による摩攃係数 が增大するため直立堤に比べて堤体の重量の低隇が図られかつ、消波ブロックも堤体重量として計算できるな どの利点期待される。

\section{4. 模型実験}

このように消波ブロック内蔵双胴型ケーソンは大水深域における種々の課題を解決する特長を持っているの でこれらを模型実験により確認する。

\section{4-1 反射波実験}

(1) 実験条件

実験は、前述の堤体の1/60の模型を用いて、スリットの開ロ比、ブロック内蔵部巾、マウンド高さを変化させ た堤体に下田港周辺を想定した実験波を作用させ、その反射波を測定することにより実施した。実験条件は以 下のとおり。( )内は現地に対応した値

開口比 : $\varepsilon=S /(S+D)=47,35,23 \%$ 消波ブロックの有る場合と無い場合

ブロック部巾： $B_{3}=28.3 \mathrm{~cm}(17 \mathrm{~m}) ， 36.7 \mathrm{~cm}(22 \mathrm{~m})$ 各々消波ブロック 3 列, 4列並びに対応

マウンド高さ $: \mathrm{hm}=8.3 \mathrm{~cm}(5 \mathrm{~m}), 16.7 \mathrm{~cm}(10 \mathrm{~m}), 25.0 \mathrm{~cm}(15 \mathrm{~m})$

実験波(不规則波) : $h / L_{1} / 3=0.096 \sim 0.574\left(\mathrm{~T}^{1 / 3}=6 \sim 20 \mathrm{~s}\right.$,

$$
\left.\mathrm{H}^{1 / 3}=2 \sim 17 \mathrm{~m}\right)
$$

$$
\mathrm{H}^{1 / 3}=0.03 \sim 0.28
$$

\section{(2) 実験結果}

○開口比：図 3 に開口比と反射率の関係を示す。これによると開 口比の影響は、周期の短い波の場合に大きくみられ、開口比が增加す るほど反射率は減少している。

○ブロック内蔵部巾：図 4 にブロックを内蔵した場合の $B_{3}$ と反射 率の関係をブロックを内蔵していない場合と比較して示す。これに よるとブロックを内蔵したケーソンの反射率は波の周期が短くなるに 従って減少するのに対して、ブロックを内蔵しないケーソンは一定の 周期で反射率が小さくなり曲面スリット堤や直立多孔壁堤と似た傾向 を示す。この結果 ブロックを内蔵したケーソンの通常波に対する反 射波の低減効果が認められた。また $B_{3}$ の大きさによる変化はあまり

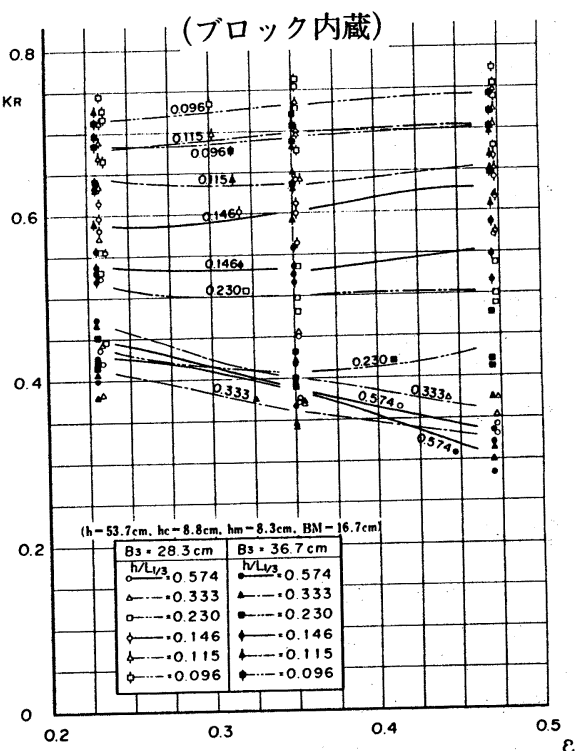

図一 3 開口比による反射率の変化 なかった。 
○マウンド高さ：図 5 にマウンド水深と反射率の関係を示す。これによると、周期の長い波において は、マウンドが高い方が反射率が低くなるのに対し 短周期波では マウンドが低い方が反射率が低くなる という逆の傾向が出ている。

これらの結果より次のことが分かった。

(1) 消波ブロックを内蔵しているケーソンは幅広い周期の波について消波効果が認められる。

(2) 開口率はブロックが抜け出さない範囲で出来るだけ広くとる。

(3)ブロック内蔵部巾は3列並びでも効果がある。

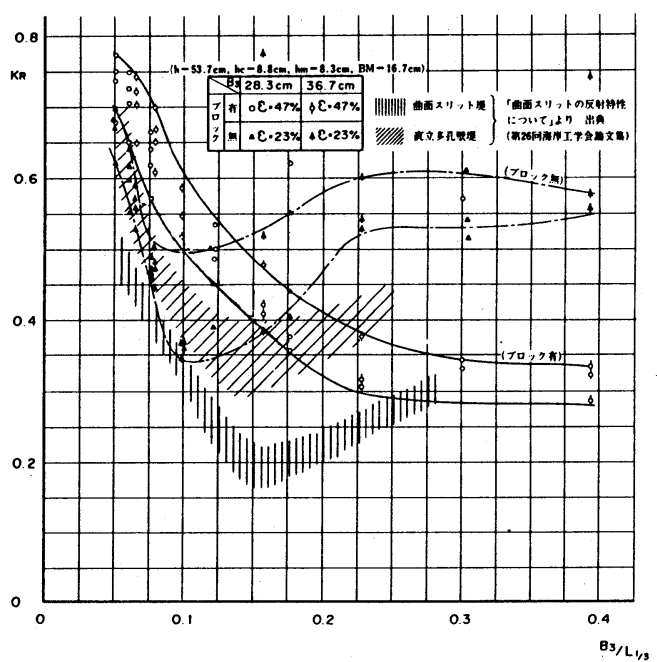

図一 $4 \quad \mathrm{~B}_{3}$ の変化による反射率

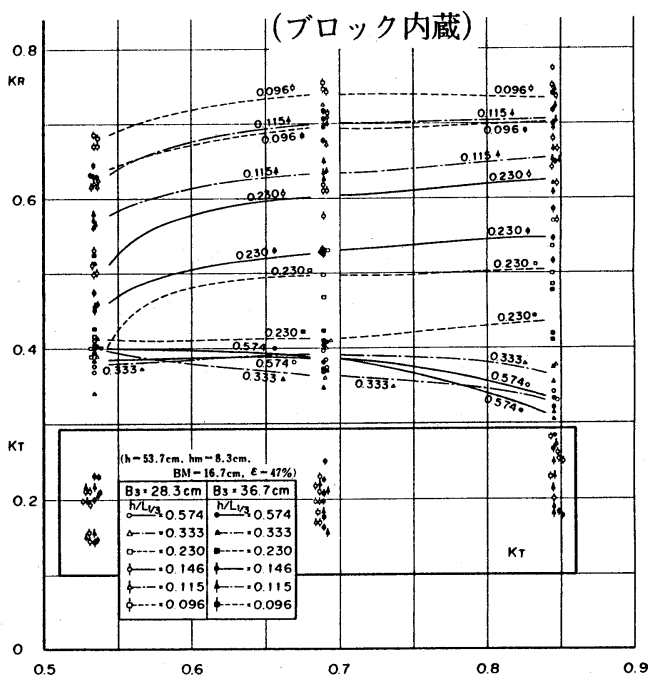

図一 5 マウンド水深による反射率

\section{4-2 波力実験}

(1) 実験条件

反射波害験の結果より開口比 $47 \%$ 、ブロック内蔵部3列並びの堤体について全体波力を三分力計により測定し 波圧の低減率を求めたほか 平均波圧強度や部材波力の測定も行った。その他実験条件は以下のとおり

マウンド高さ： $\mathrm{hm}=8.3 \mathrm{~cm}(5 \mathrm{~m}), 16.7 \mathrm{~cm}(10 \mathrm{~m}), 25.0 \mathrm{~cm}(15 \mathrm{~m})$

実験波(規則波)： $\mathrm{T}=(14,17,20 \mathrm{~S}), \mathrm{H}=8 \sim 16 m$

\section{(2) 実験結果}

○波圧低減率 $\lambda_{1}, \lambda_{2}$ ：消波ブロック被覆堤にお ける全体波圧は合田式を用いて以下のように表され る。

$\mathrm{Pc}($ 全体波圧 $)=1 / 2\left\{1+\alpha_{3}+\left(1+\alpha_{4}\right) h c^{\prime} / h^{\prime}\right\} \mathrm{P}_{1} h^{\prime}$

$$
\begin{array}{ll}
\mathrm{U}(\text { 全揚圧力 })=1 / 2 \mathrm{PuB}-(2) \\
\mathrm{P}_{1}=\lambda_{1} \alpha_{1} W_{0} \mathrm{H}_{0} & \alpha_{4}=\max \left\{\left(1-\mathrm{hc} / \gamma^{*}\right), 0\right\} \\
\mathrm{hc} c^{\prime}=\min \left\{\eta^{*}, \mathrm{hc}\right\} & \mathrm{Pu}=\lambda_{2} \alpha_{1} \alpha_{3} \mathrm{H}_{\mathrm{D}}
\end{array}
$$

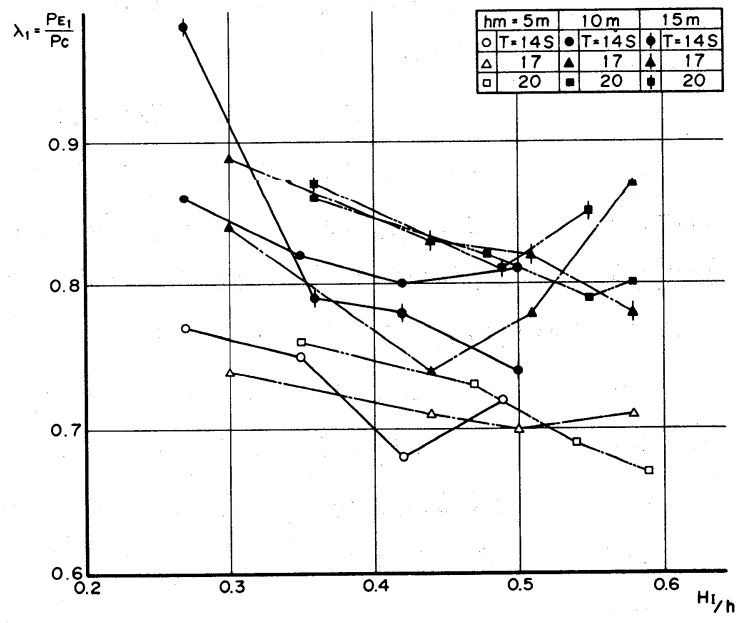

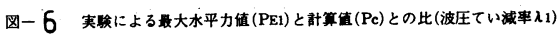


いま、(1)（2）式において $\lambda_{1}=\lambda_{2}=1.0$ とした場合の波 圧に対する実験値の割合を波圧低減率と定義すると

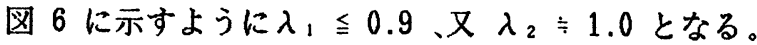
しかるに双胴型の構造であるため、水平波力最大時と 鉛直波力最大時に図 7 に示すようなタイムラグが生 じるため、これを考虑すれば実際には $\lambda_{2}=0.6$ 程度 となる。

○平均波圧強度は水平波力 $\mathrm{Ph}=0.7 \mathrm{~W}_{0} \mathrm{H}$

鉛直波力は $\mathrm{Pv}=0.7 \mathrm{~W}_{0} \mathrm{H}$ となった。

○部材波力：図 9 に部材波力の分布(マウンド高さ $5 m$ の場合)を示す。それによると 水平波力はスリット前面 でP $=1.1 \sim 0.65 \mathrm{~W}_{0} \mathrm{H} ，$ スリッ卜背面 $\mathrm{P}=0.9 \sim 0.5 \mathrm{~W}_{0} \mathrm{H}$

, 背後壁前面で $\mathrm{P}=0.95 \sim 0.55 \mathrm{~W}_{0} \mathrm{H}$, 揚圧力はP $\mathrm{Pv}=0.7$ 〜 $0.6 W_{0}$ Hで通常の三角形分布を示さなかった。無底函部 については、下向きに $0.9 \mathrm{~W}_{\mathrm{O}} \mathrm{H}$ ，上向きに $0.6 \mathrm{~W}_{0} \mathrm{H}$ となり下 向きが大きくなった。

\section{4-3 滑動実験}

\section{(1) 摩攃係数}

通常の直立堤の場合、ケーソン底部のマウンド間の摩攃 係数は0.6とされるが消波ブロック内蔵双胴型ケーソンの場 合、無底函部の捨石とマウンド間のかみ合わせによる摩攃 保数の增大が考えられる。このため樎尺 $1 / 600$ 模型を用い て無底函部の捨石の有る場合と無い場合について堤体重量

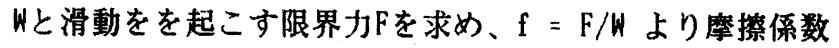
を求める。図10 にその結果を示す。これによると、捨石 の有る場合は $\mathrm{f} \geqq 0.7$ となるのに対し、無い場合には $\mathrm{f} \leqq 0.6$ と明確な差が認められた。

\section{(2) 滑動限界波高}

滑動に関しては堤体の)水中重量 Pcの間には以下の関係がある。

$$
\mathrm{Pc}=\mu\left(W_{0}-U\right)-(3) \quad \mu=\text { 摩摖係数 }
$$

いま、水中重量 $64.5 \mathrm{~kg}$ (約14,000t 一 中詰に砂を用いた場 合に相当）、47.2kg(約10,000t 一 中詰に海水を用いた場合 に相当）、55.2kg(約 $12,000 \mathrm{t}$ 一両者の中間) の堤体につい て波高と滑動量の関係を求め、それを(1)(2)(3)式において $\mu=0.7, \lambda_{1}=0.9, \lambda_{2}=0.6$ とした場合に求められる 滑動限界波高 He と比較すると図 11 〜 13 のようになる。 これによれば 堤体重量が軽い場合に両者に若干の相異がある ものの両者は一致しており、 $\mu, \lambda_{1}, \lambda_{2}$ の值は妥当なものと 判断される。
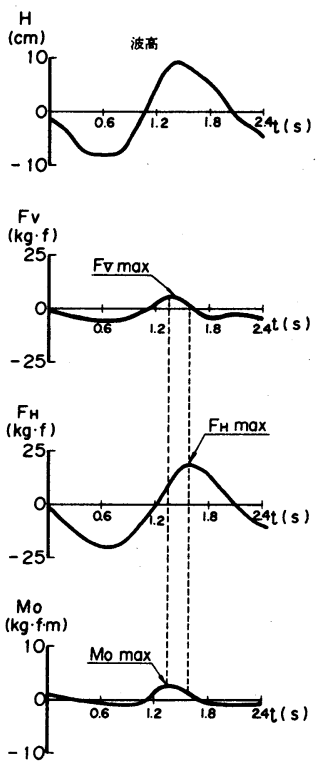

目一－３分力計及び波高記録
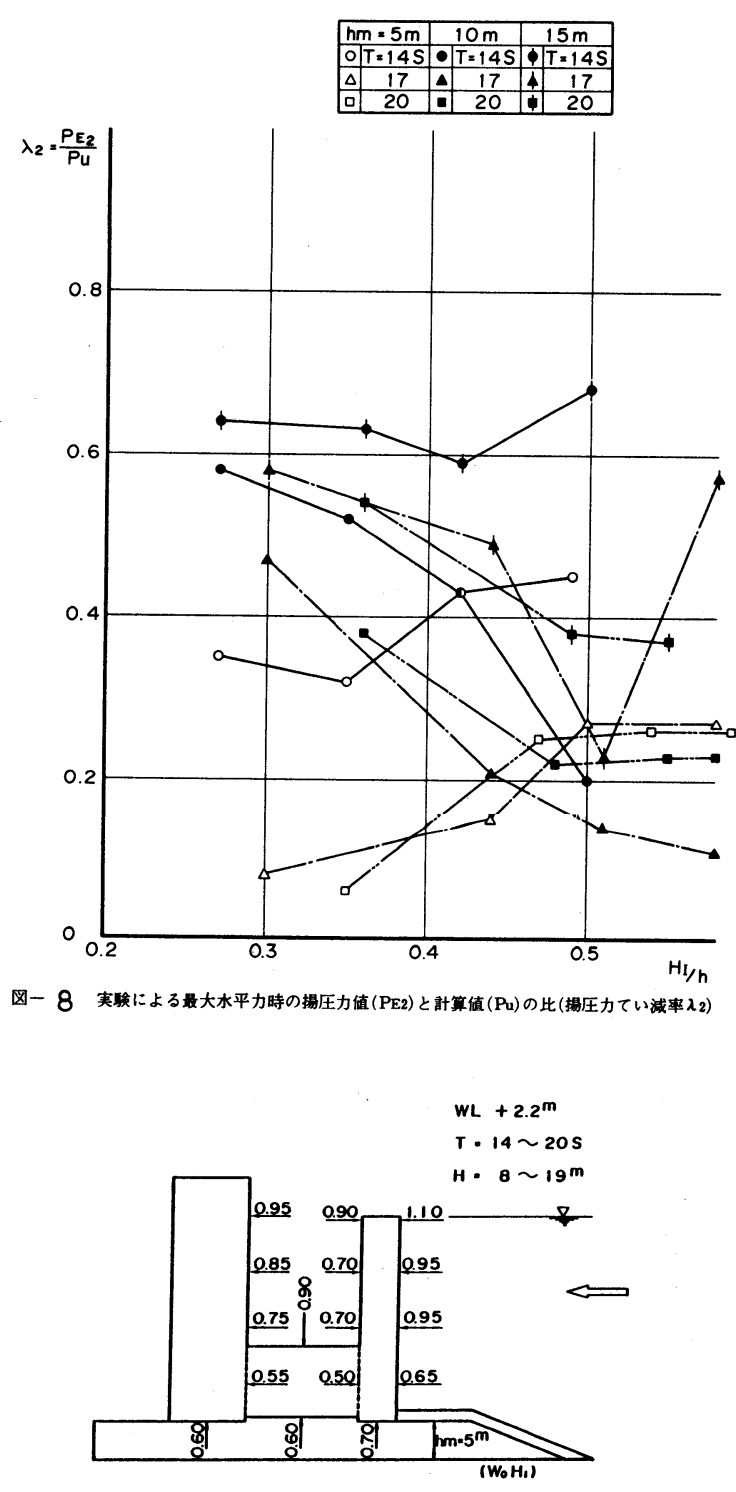

図一 9 部材波圧分布 $(h \mathrm{hm}=5 \mathrm{~m})$ 


\section{(3) 堤体重量}

(2)で求めた滑動限界波高 H と同じ限界波高を示す直立堤の 重量 W。c は以下により求められる。

いま、(1)式において $\quad P_{1}=\left(\alpha_{1}+\alpha_{2}\right) W_{0} H ，(2)$ 式におい $\tau \mathrm{Pu}=\alpha_{1} \alpha_{2} W_{0} H$ とすると

$$
\begin{gathered}
W_{0} c=\frac{H[}{2}\left[\left\{1+\alpha_{3}+\left(1+\alpha_{4}\right) h^{\prime} c^{\prime} / h^{\prime}\right\} \frac{\left(\alpha_{1}+\alpha_{2}\right)}{\mu}+\alpha_{1} \alpha_{3} B\right. \\
(\mu=0.6)
\end{gathered}
$$

各堤体重量、各周期の波について W。c と と図 14 に示すとおりとなり、いずれの場合についても、2 割以上の堤体重量が節約になる。

以上のような結果から消波ブロック内蔵双胴型ケーソンに ついては、以下の点が確認された。
(1) 反射波の低減効果
(2) 波力の低減効果
(3) 摩㩯係数の增加
(4) 堤体重量の節減
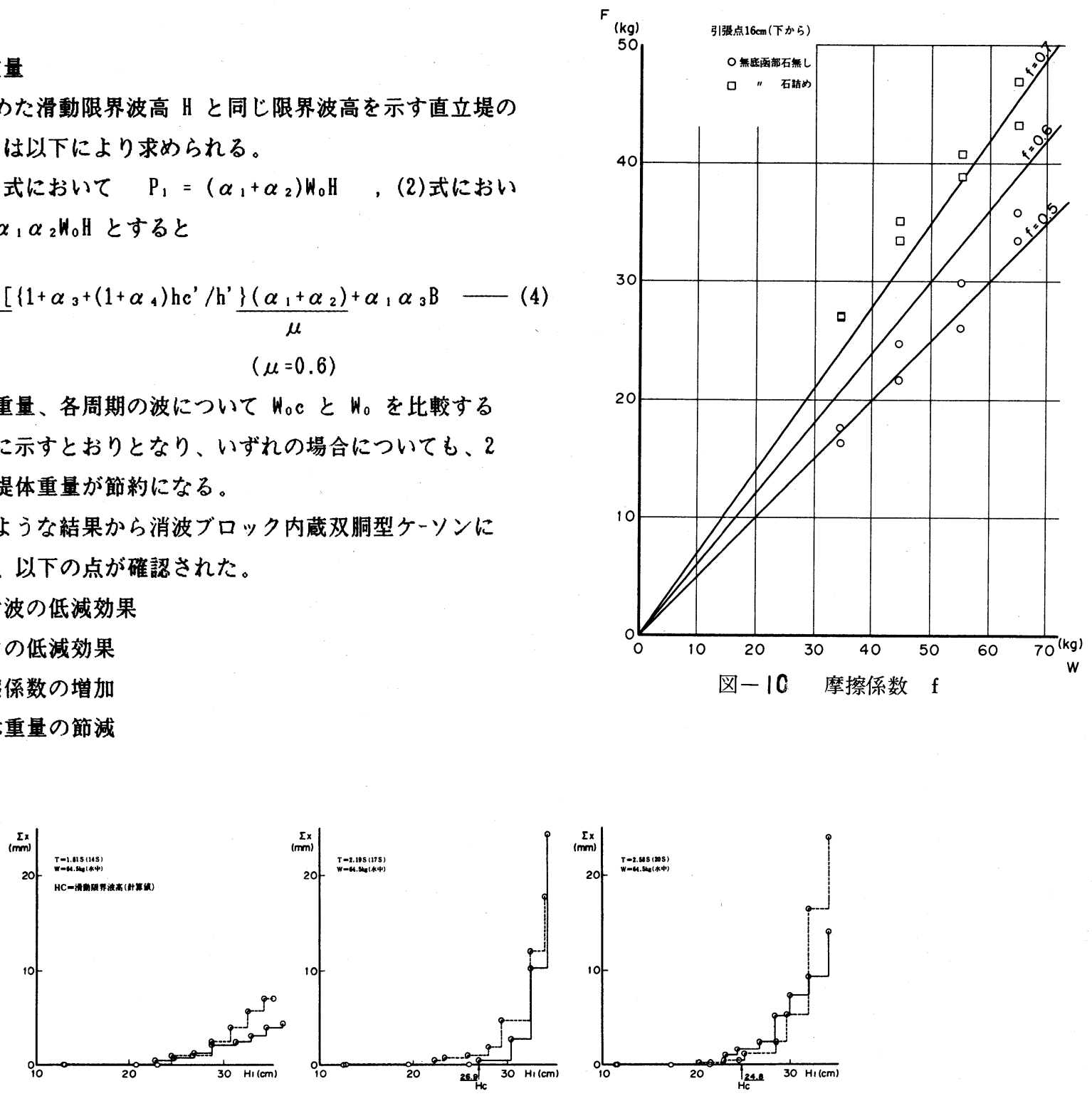

図一１＜wide>滑動限界波高と移動量 $(\mathrm{W}=64.5 \mathrm{~kg})$
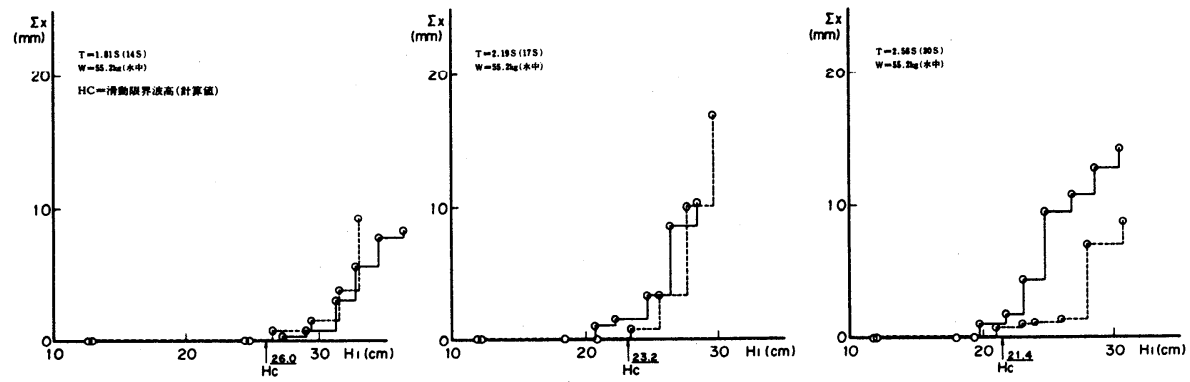

図一 12 滑動限界波高と移動量 $(\mathrm{W}=55.2 \mathrm{~kg})$
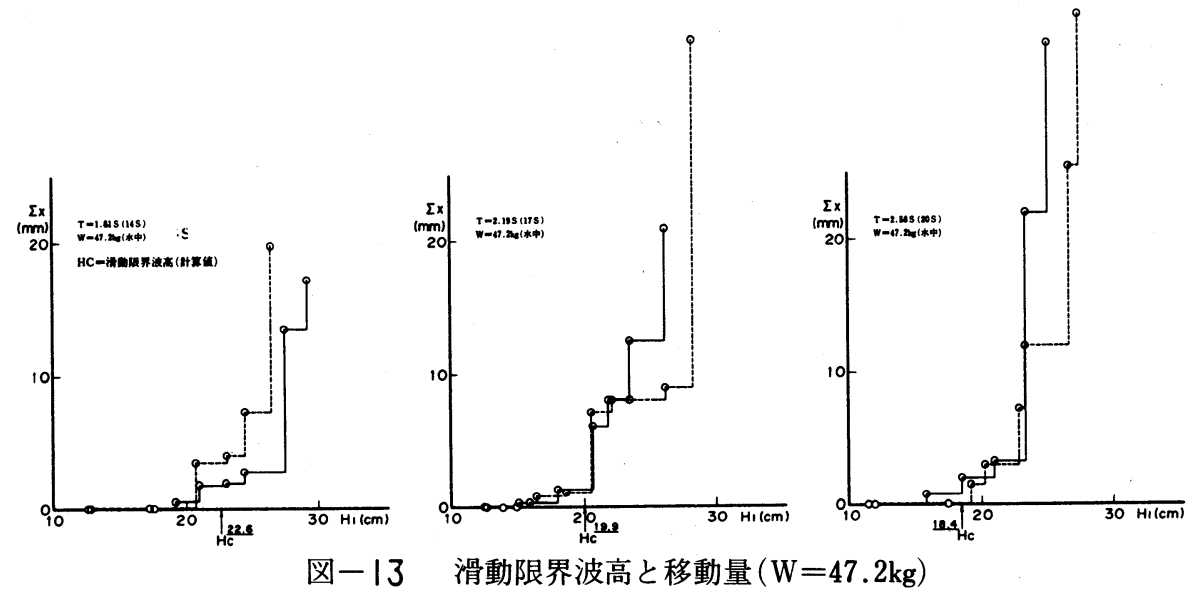

図一13 滑動限界波高と移動量 $(\mathrm{W}=47.2 \mathrm{~kg})$ 


\section{5. 今後の課題}

この実験により消波ブロック内蔵双胴型ケーソン堤は期待 されていた利点をそなえていることが確認されたわけである が、さらにこの新構造形式の実用化に向けていくつか解決し ておかなければならない課題がある。

(1) 堤体の安定性 : 無底函部の捨石とマウンドのかみ合わせ による摩摖係数の増大は確認された。ただ、無底函部捨石の 転倒に対する抵抗についてはさらに検討を行う必要がある。

(2) マウンドの安定性：マウンドの勾配は一般に港外側 $1: 2$ $1: 3$, 港内側 $1: 1.5 \sim 1: 2$ 程度となっているが大水深, 大波浪 域においては長周期波の影響も考えられるため、その安定性, 勾配や所要重量などを模型実験により確かめる必要がある。

(3) 施工法：堤体は大きな構造でしかも非対象であるため、 その製作や運搬、現地での据付方法なども通常のケーソンと同 様には行えないため、新たに検討する必要がある。

(4) 構造：堤体前部の直立柱は、後壁と板でつながっているに 過ぎないため、水平波力や内藏しているブロック圧や不等沈下 に対する構造解析を行う必要がある。

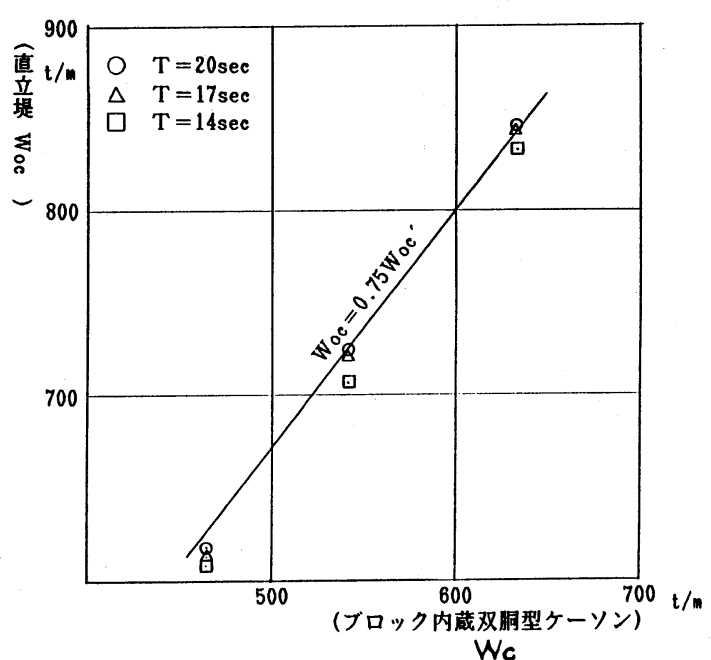

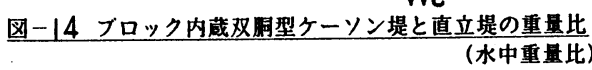

